\title{
HOW PEOPLE IN ZALA COUNTY SEE SECURITY IN TOURISM
}

\author{
Erzsébet PÉTER ${ }^{\mathrm{a}}$, Kornél NÉMETH ${ }^{\mathrm{a}}$, Andrea KATONA ${ }^{\mathrm{a}}$, \\ Nikoletta GÖLLÉNY-KOVÁCS ${ }^{\mathrm{a}}$, Ildikó LELKÓNÉ TOLLÁR ${ }^{\mathrm{a}}$
}

\author{
${ }^{a}$ University of Pannonia, Nagykanizsa Campus, Institute of Applied Management Sciences, Email: \\ peter.erzsebet@uni-pen.hu, nemeth.kornel@uni-pen.hu, andrea.olajos@gmail.com, kovacsnikoletta@ \\ ktk.pte.hu, tollar.ildiko@uni-pen.hu
}

Cite this article: Péter, E., Németh, K., Katona, A., Göllény-Kovács, N. Lelkóné-Tollár, I. (2019). How People in Zala County See Security in Tourism. Deturope, 11(1), 95-116.

\begin{abstract}
Events all around the world bring new challenges not only to tourists and tourism professionals, but also to law enforcement agencies. Today's new law enforcement challenges include, besides general police tasks, the elimination of terrorist threats in tourist destinations and at special events. Professional difficulties involve the lack of local knowledge of the stationed personnel, the estimated time of arrival at the venue, and the limitations of observation and communication in large crowds. The study, among other things, seeks to find out how recent events have influenced the leisure habits in tourist destinations and event venues, furthermore, whether news in the media generate a sense of security or mistrust in humans. If we go beyond the classical sense of security that is the freedom from unlawful acts, namely, from terrorist attacks, we should also mention many elements of technical security. The broad sense of security includes safety of the environment (built and natural), consumption and health. However, we can take a different view. Not only the tourists' safety needs to be emphasized and focused on, but safe tourism is also important for the residents in the tourist destination. In addition, there is an emerging trend that prefers nature and tranquility to busy cities and resorts bustling with tourists. The research seeks to find out what factors affect the employees in Western Hungary and the consumer behavior in tourism in Zala County, along with the cultural and social characteristics and the psychological needs (e.g.: motivation, perception, attitudes). How consumers see the security of tourism and what are the aspects that may be important when choosing a holiday destination. What kind of responses the agencies in tourism sector have had for security issues in recent years, which can prevent problems and increase the sense of security for those who want to relax.
\end{abstract}

Keywords: tourism, security, consumer demands

\section{INTRODUCTION}

\section{Significance of safe destination}

Tourism is one of the constantly growing industries in the world, which has recently been influenced by political instability and terrorism. This trend has an impact on demand for potential tourists and significantly influences tourism (Sönmez, 1998). World tourism is affected by economic crises, the external environment, natural disasters, and political conflicts, which determine the destinations the tourists choose (Ritchie 2004). 
International conflicts between countries play a significant role in the development of target images. The negative events in a region have a damaging impact on the tourism sector of the region (Alvarez \& Campo, 2014; Rittichainuwat \& Chakraborty, 2009; Thapa, 2004).

Security and safety has become a complex multidimensional notion with a wide range of components belonging to it: political security, public safety, health and sanitation, personal data safety, legal protection of tourists, consumer protection, safety in communication, disaster protection, environmental security, getting authentic information, quality assurance of services etc. Security has undergone a significant change: from a more or less passive factor it is now an active element of tourism, an imperative to act in order to protect tourists and their belongings as well as all the achievements of the industry (Kővári \& Zimányi, 2017).

Security is a prerequisite for the development and successful improvement of the tourism industry (Pizam \& Mansfeld, 1996; Hall \& Timothy-Duval, 2004). If a tourist destination cannot eliminate the threats against those arriving there and give a sense of security, it cannot be considered competitive even if the local conditions are. Security nowadays determines the functioning of an existing or potential tourist destination to such an extent that security factors can be interpreted as the prerequisites of the tourism industry (Michalkó, 2012, 2019).

Thanks to the rapid development of tourism, as well as the differentiation and the mediafriendly appreciation of security risks, the modern interpretation of tourism security now means much more than focusing on infringements. While tourism-related security risks (crimes, offenses) remain crucial, more and more attention is being paid to the risks associated with health, infrastructure and the social environment, which often overlap with one another and with the infringements.

Tourism is essentially an industry based on trust and one of the most important foundations of its complex system is security. The problem of security, of course, raises extremely diverse issues ranging from natural disasters, terrorism, and financial processes to accommodation services, the environment, food, health, or transportation. In tourism, preconception and experience are dominant factors in decision-making. The former involves the political environment, the safety of transportation (airports, planes, trains), the safety of the natural environment (water quality, tsunamis, volcanic eruption) and cross-border terrorism that threatens everyone (Péter, Németh, \& Lelkóné Tollár, 2018). During travelling, our first choice is a safe destination, followed by entertainment opportunities and event venues that interest us. Organizers have to exercise extreme caution when planning an event. There may be multiple laws regarding a given event depending on whether it is organized in a building or in the open air, or how many participants are expected. Not only the organizers of large-scale events, but 
also the mayors of local governments arranging rural fairs or end-of-the-year parties should be acquainted with the relevant regulations (Király \& Vájó, 2015).

Public safety basically covers offenses falling under the authority of the police. Minor and major violations committed against tourists include pick-pocketing, vehicle burglary or stealing luggage and valuables from hotels and railway stations.

Cities and popular tourist destinations are now trying to do their best to prevent the terrorist threat. Following the Barcelona van attacks, the centers of Italian cities are enclosed, one after the other, blocking the wider streets, seafront promenades and monuments with concrete blocks, cordons and large flower boxes (Németh \& Péter, 2019).

Similar precautionary measures have been introduced in German cities. The safety of outdoor events is of paramount importance everywhere. For example, in the province of Hessen, all seven police headquarters are ready to deploy special units to take action if necessary without any time loss. In most major cities, the area of events is surrounded by cordons and, at the strictly controlled entrances, concrete elements are also installed to prevent truck and truck attacks. In order to avoid harassment against women, refugee shelters in many provincial metropolitan areas are provided with multi-lingual leaflets on equality between women and men and on the right to self-determination.

On 2 February 2019, the yellow vest movement repeatedly called for demonstration, warning tourists and the local population to avoid demonstration routes in the French capital and in several major cities (Bordeaux, Toulouse, Marseille, Valence). In Paris, 5,000 people were mobilized by the authorities to curb any unrest that might occur, and borders are strictly controlled. Military presence at railway stations and airports is significant. Tourists often fall victim to pick-pocketing, hotel theft and vehicle burglary. In case of hotel theft, it is advised to ask for the details of the hotel's insurance company, too, because under the French Civil Code the hotel assumes joint and several liabilities for theft in its territory. However, insurance companies will only reimburse for damage supported by invoice, and in case of cash theft they insist on the presentation of a bank receipt document.

Under French law, hotels are required to complete a police form with all foreign guests. In addition, all facilities are authorized to carry out security checks if necessary (Department of Consular Affairs and Citizenship, 2019).

Health security is also very diverse, ranging from pollen allergies to hepatitis infection for unprepared tourists. Travelers can actively contribute to increasing the health risk of the destination they visit by carrying a wide variety of pathogens (in particular, contact with HIVinfected people is considered dangerous to host society in sex tourism). Crimes risking human 
health involve drug-related offenses that primarily are relevant to tourism (drug trafficking, possession of drugs). In many countries, trafficking (and, of course, using) even small quantities of drug is punished severely, sometimes by death penalty (e.g. Thailand, Indonesia, Singapore, Malaysia, Iran). The reverse happens when the host country's drug policy is more permissive and tourists purchase drugs through the laws of the host country, which are later taken out of the country; it is considered a crime (e.g. the Netherlands). It is worth mentioning here Thailand has a military government, which results in tense security situation, and health security is not the best either. Malaria, dengue fever and chikungunya virus also occur. In recent years, the number of dengue infections has been particularly high, so it is advised to take precautions against mosquito bites not only in rural but also in urban environments.

Consumer safety, which avoids the annoying inconvenience of the traps installed by service providers, affects the tourists and the local population equally. Some taxi drivers and hospitality units overbill the services, while traders harm the travellers by selling low quality goods or fake products.

Danger may arise from the use of all infrastructure facilities and service units. The greatest safety risk is the transportation infrastructure; accidents caused by transport vehicles, deficiencies in road and rail networks are significant. Travellers may be not only victims, but they may also cause incidents; for example, a bus in a bad state of repair or a burning cigarette in a hotel room may lead to catastrophes. Some traffic accidents and crimes are related to the consumption of alcohol or drugs. Alcohol abuse violations are partly due to differences in blood alcohol thresholds in each country. There are zero tolerance laws in four countries in Europe (Hungary, Romania, Slovakia, Czech Republic), while in other countries a certain amount of alcohol is allowed. On the other hand, we can say that in many cases tourists have a loose interpretation of regulations that applies to them when they are far from home. Moral norms in traffic and bad roads also cause tragic accidents on Egyptian roads. Accidents are mainly caused by human error. The majority of holidaymakers in Egypt do not have good subjective perception of safety on the roads.

On the one hand, navigational safety means giving information and direction in order to reach the destination without any problems, on the other hand, it facilitates the mastery of a given culture. If the tourists get lost, the lose time and wandering around consumes their energy; the worrying may distract them and they can even get into serious danger. In many cases, local rules and habits may be crucial; knowing what to do when warning signals are detected, how to dress, or how to use means of transport can help prevent accidents, difficult moments, and conflicts. 
By giving an Egyptian example, it is important to know that in Egypt begging for baksheesh is a common phenomenon. Children usually surround the tourists, then more and more people gather around them asking for money; you should not give them anything and they will disappear. This behavior can prevent some theft. The hotels are safe, there are safety deposit boxes everywhere. Since general hygiene conditions are also different from European standards, we have to protect ourselves against diseases that spread with contaminated food, drink and tap water.

The economic instability of a tourist destination can also have a major impact on demand. Bayramov and Abdullayev (2018) studied the influence of political conflict and terrorism on Turkey's tourism indicators and competitiveness. Turkey has been challenged by political conflict, and several associated terrorist attacks in recent years. Consequently, the risks involved in visiting one of the world's top tourism destinations, Turkey, have increased. Crisis has challenged the country's competitiveness and share in world tourism as a top tourist destination. Studies on the effects of this on tourism have shown that conflict has a significant, negative impact on a region's tourism industry. The results show that there is a strong relationship between the changes in the terrorism index and overall tourism growth rates. Political conflict and terrorism have an adverse effect on Turkish tourism development.

In order to protect an event attracting both tourists and local residents, the police used to provide double security (i.e. external and internal). The external protection is carried out by law enforcement groups, such as the traffic police or the public order division. This area consists of the streets outside the event venue; the basic goal is to create an external filter to eliminate disturbing behaviour and crimes (vehicle burglary). They set up checkpoints to be able to protect the scene and to deal with the crowd in a safer and more comfortable way. The past few years have brought highly significant changes in world tourism. Unfortunately, in the threatened areas the locals also fall victim to the increasing crime, and they have to tolerate mass tourism with all its negative effects, e.g. lack of tranquillity. The deviant needs of the masses must be served; organized crime based on prostitution, child trafficking and forced labour emerge. The most vulnerable groups are at increased risk: children, women, young people are the most likely victims. It is therefore of utmost importance to talk about the dark secrets of the glittering world of the travel market more frequently. However, there are many existing or evolving future destinations, where these phenomena are not present, and visitors consider them a haven of peace (Ernszt, Péter, Keller, \& Tóth-Kaszás, 2018).

The essence of tourism is to experience temporary changes offered by the services. Tourism security means the lack of threats hindering the effective functioning and development of the 
tourism market. Tourism security decreases or prevents the risks of temporary stay threatening both the traveller and the destination (Michalkó, 2012).

\section{THEORETICAL BACKGROUND}

\section{The security of tourism in international tourism}

Looking at the current political turmoil across the globe, we aim to analyze the effects of interaction between political instability and terrorism on tourism development using panel data from 139 countries for the period 1999-2009. The study analyzes the extent to which a country's political conflicts and terrorism can negatively impact its tourism industry. The results reveal that the effect of political instability on tourism is far more severe than the effects of one-off terrorist attacks. Surprisingly, the findings suggest that terrorist attacks increase tourism demand for countries with low to moderate political risk. However, countries that experience high levels of political risk witness significant reductions in their tourism businesses. In addition, political volatility and terrorism together can cause serious damage to the tourism industry.

Cleanliness and security in and around the tourist sites are a key concern for foreign tourists. Disasters create difficult, often tragic situations for the affected area and its residents.

There must be forward-looking policies set out by both the government and other sections of society interested in promoting tourism in order to deal with terrorism while not hurting tourism (Ranga \& Pradhan, 2014).

Risk perception in tourism is associated with the issue of safety in travel, and results in an impact on tourist's travel decision and destination choice (Sonmez \& Graefe, 1998). When potential tourists plan a holiday that is risky, this generates a fear of negative consequences. Consequently, those perceived risks and perceptions of safety may cause potential travelers to cancel their travel plans, change their destination, modify their travel behaviour or obtain more information. A tourist's decision-making process is influenced by the individual's external and internal factors. Several internal factors related to terrorism may influence every key stage of the decision-making process.

Tourism competitiveness is measured by the Travel and Tourism (in the following: T\&T) Competitiveness Index (TTCI) provided by the World Economic Forum (WEF) in the TTCI Reports of given years, for 136 countries of the world. TTCI is a composite index, that is a weighted average of 14 indices (called ,pillars”) describing the environment in which tourism operates. These include the actual safety and security index of the same year, which, again, is a weighted average of several safety and security related measures (Crotti \& Misrahi, 2018). 
Yet, to date, Europe remains the largest T\&T market, almost twice as large as Asia-Pacific, the second largest and rapidly growing market.

While the number of arrivals continues to grow in Europe, international revenues started to decline in 2015, suggesting possible re-adjustments in the sector at the regional level. Different hypotheses can be put forward to explain this phenomenon. For instance, given the importance of intra-regional travel, lower spending may reflect lower purchasing power and more attention towards lower-cost travel solutions. At the international level, shifts in international arrivals from North America to Asia may entail shifting spending patterns. As these trends evolve, the continuous improvement of the sector's competitiveness will be essential in light of the industry's transformation, especially in the more mature destinations.

The country's religious affiliation is also important in the destination choice for international tourism. A cross-country study of 164 countries (Fourie, Rosselló, \& Santana-Gallego, 2015), for the period 1995-2010 provided evidence that religious similarity has significant explanatory power in global tourism. Religious or ethnic diversity may be the consequence of international labour migration, which, later, may boost the tourism flows between the region of origin, and the host area (Bacsi, 2019).

In the Balkans and Eastern Europe, price competitiveness is strong, but the sub-region has not invested enough in air connectivity and cultural resources yet (Fig. 1).

Figure 1 The Travel and Tourism Competitiveness Index in Europe in 2017 (Safety and Security)

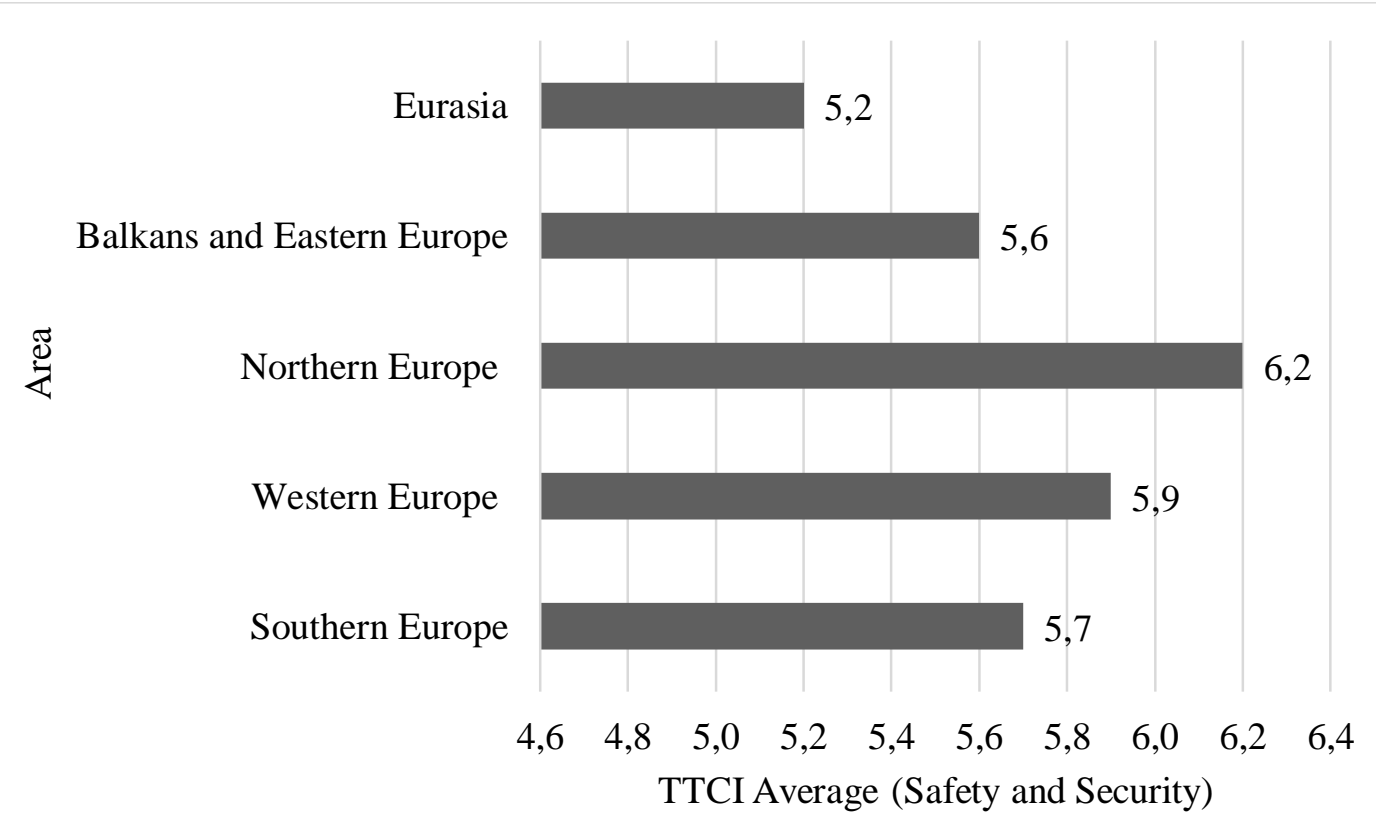

Source: Created by authors based on World Economic Forum (2017) data 
At the same time, international openness tends to be weaker than in Western Europe. The Eurasian sub-region also faces issues relating to international openness and transport infrastructure. Yet this sub-region boasts more qualified and efficient human resources while, at the same time, providing more price competitive options, thanks to lower hotel prices and fuel costs.

Hungary's 5.7 average is ranked 45 th out of 136 countries, which means that tourists consider it safe.

A total of 22.4 million foreign tourists came to Hungary in 2017; their number increased by $4.3 \%$ compared to 2016 . Tourists spent a total of 83.7 million days in our country. $63 \%$ of the tourists stayed for more than one day. The number of tourists arriving for several days (14.1 million) rose by $4.7 \%$, the number of overnight tourists ( 8.3 million) increased by $3.8 \%$ in 2017 . Decrease in travel time is an international trend (KSH, 2018). Data on Hungary's safety record is very good, while in Spain and the United Kingdom the terrorist threat was high in recent years, so preventive measures were necessary to protect the population and tourists.

Thanks to Hungary's strict migration policy, Budapest is Europe's safest capital and is directly accessible from the United States. In addition, Budapest is also the sportiest capital in the world due to a series of sports events organized in the city. Moreover, the Asian tourist arrivals to Budapest are increasing year by year.

Rising domestic tourism also indicates that Hungarians are more inclined to travel to Budapest, but at the same time, the capital has been able to expand more in several source markets: the US, Southwestern European (Spain, Portugal), Israeli, Ukrainian and several Asian markets had a double-digit increase in 2018. Today it seems that the Far East's superpower, China, has the greatest tourism potential for Budapest: in 2018, 199,913 Chinese guests (+ 14.4\%) spent about 329,081 nights $(+14.9 \%)$ in the Hungarian capital, and they stayed mainly in hotels (BFTK, 2019).

\section{Changing trends in consumer habits}

According to the Maslow model (1954), individuals at different hierarchical levels of demand satisfaction want to travel for different reasons due to different motivations. The desire for rest, the desire to escape, or the desire for self-realization at a higher hierarchical level are motivations for travelling (too), which can be derived from the socio-demographic and psychological characteristics of the individual and are influenced by the gender, age, social status, income of the tourist, and many other factors. However, the Maslow model cannot explain what destination the tourist will choose and why. In the second half of the seventies, 
various tourism motivations were categorized into a comprehensive logical framework, based on Tolman's (1959) behavioural psychological research. Reviewing the scientific research on tourism motivations, Dann (1977) concluded that although there is a lot of confusion and sometimes it is difficult to determine whether researchers are actually studying the same phenomenon, basically two approaches can be identified.

Travel can be seen as a response to a need missing from the tourist's life. The activity of travelling and the characteristics if the destination pull (attract) the tourists by responding to the motivation. The two approaches represent two groups of tourist motivations identified by Dann (1977) and categorized as push and pull motivations. Push motivations represent the inner desires that push the tourist towards the journey. The pull motivations are the tourist's perceived and appreciated characteristics of the destination; they pull (attract) tourists to the destination. The destination's pull factors are assessed by the tourist in the light of his / her own motivation (push).

During travelling, the well-being of tourists is based on physical safety and health. Besides these essential factors, however, well-being is associated with satisfaction and emotional balance as well. Naturally, these desires do not emerge in our mind by themselves. The desires to travel for pleasure and to leave the privacy and safety of our home are driven by an extremely sophisticated system, and the tourist rarely recognizes the local authenticity, culture and lifestyle advertised by the marketing. This logic suggests that the tourist desires can never be fulfilled. The constructionist and reflexive approach to authenticity, however, crosses the border between reality and the scheme offered to the tourist. This does not eliminate the constructive, selective and branding procedures of the tourism industry, but it does make it clear that the satisfaction of the tourist does not necessarily depend on them (Pusztai, 2013; Bacsi \& Kovács, 2016).

Recreational events, linked to other tourism products, make it possible to create a full range of products in order to extend the tourist season. As far as the European trends in the festival market are concerned, it can be concluded that in 2017 the impact of the crisis can still be felt, but as a whole the market is growing. The large, multi-day festivals are becoming more and more popular, and the events may be specialized. The most important and most decisive trend for this tourism product is slow travel; moreover, event tourism also starts emphasizing the accessibility of the destination as well as the security issues. In the last decade, we witnessed a decrease in territorial concentration in event tourism: many rural events and festivals have intensified offering quality programs to their visitors annually, and their organization and marketing communication are constantly evolving. Thanks to the strong state involvement, we also organize many major international sports events, partly due to our centuries-long 
achievements in certain sports and partly through our sport lobby activities (swimming, water polo, fencing, handball, football, etc.). Sports events attract more and more tourists and the number of spectators is increasing dynamically year by year (Hungarian Tourism Agency, 2017).

The Tourist Police is a special service in the preventive work of law enforcement agencies aimed at preventing crimes and helping the tourists in trouble. In order to provide tourist information in Hungary, most of the Tourist Police organizations are accompanied by appropriate foreign language interpretation. The Tourist Police work is mostly needed in the most visited regions, usually serving in the summer high season (Oláh, 2010).

Tourism Online (2018) reports that a significant proportion of travellers decide to explore the lesser-known parts of the world in $2017.45 \%$ of respondents plan to choose a destination offering more adventurous experiences this year, while $47 \%$ want to go to a place where none of their friends have been before. Whether it is hiking in an isolated mountain village or some other unusual experiences, people have a growing desire for adventures to discover previously unknown areas in a unique way.

Although technology is becoming more and more widespread in all areas of our lives, real human relationships and the interaction with the hospitable staff are also appreciated. As mobile phones and social media are entering the private sphere increasingly, tourism providers can contact consumers on multiple platforms (Simay \& Gáti 2017, Bogáromi \& Malota, 2017). According to the results of our empirical research, the majority of people would not stay in a place where the staff is unfriendly and unhelpful, while the popularity of private accommodation that builds direct contact grows steadily.

In their study, Bogáromi and Malota (2017) sought to find out the way European tourists look at Hungary. In terms of country image, issues of security and hospitality were in focus. Quantitative data collection was carried out in the summer of 2017.

CAWI method was used, the sample consisted of respondents aged 18-65, who have traveled at least to two countries during the last 4 years, and at least one of the visited countries was an ex-socialist country. The representative sample comes from 8 countries: The United Kingdom, France, Italy, Germany, Sweden, Austria, Poland, and the Czech Republic.

The study by Bogáromi and Malota focused on safety, so they asked the respondents how safe they felt Hungary and Europe. The number of people travelling in Europe is steady, since the migrant crisis was insignificant in every country (5-12\%). Most respondents consider Europe less safe in terms of travelling and holiday-making. 24\% of the French and $63.9 \%$ of the Polish respondents deem travelling in Europe less safe since the beginning of the migrant 
crisis. The proportion of those who see travelling more dangerous than before vary between the lowest 23.6\% (Polish respondents) and the highest 51.6\% (French respondents).

The annual number of Hungarians traveling abroad has increased by $19 \%$ over the past 10 years, from 17056 to 20297 . The average stay fell from 3.1 days to 2.8 days, while spending increased. Between 2007 and 2017, Hungarian tourists spent 63\% more on foreign travel, which was EUR 816,487 million in 2017. It means that we spend less time travelling but spend more.

According to an international study in 2018 (IPSOS, 2017), 54\% of European travellers deemed rest and relaxation, while $44 \%$ the time spent with family and friends during their holidays the most important. At the same time, Europeans considered safety-related aspects when choosing their destination, right after costs and weather. For Hungarians, the most important aspect when planning a holiday abroad is to spend enough time with their families and friends. We value security abroad more than adventure - while price, of course, remains an essential factor for everyone. Ladies with families are especially thoughtful, with nearly 60 percent mentioning safety as one of the most important aspects. It is not surprising, of course, that young people have desire for discovery, along with the joy of spending time with friends and the need for security (IPSOS, 2017).

Croatia was the number one foreign destination among tourists in 2017 , with $24 \%$ of travellers choosing our southwestern neighbour. Greece (13\%), Transylvania (12\%) and Italy (10\%) are very popular, but Spain (7\%), Germany and Austria (5.5\%) are also among the preferred countries. The decision of the 20-29-year-old Y-generation is interesting: most of them are planning a European trip but instead of targeting the above-mentioned 'classic' summer destinations they choose Denmark, Ireland or the Netherlands. 10\% travel overseas and others visit North Africa, Asia and Australia (Turizmus Online, 2017).

\section{DATA AND METHODS}

The quantitative research involved omnibus research by questionnaire. The sample population involved 508 people, $49 \%$ of whom were men and 51\% women. The survey represented the active workers in the Zala county by gender. We applied random selection when choosing samples (Barna, Nagy, \& Molnár, 2006). We used Equal Probability Sampling (EPSEM, based on the data of the employees in Zala County) after determining the representative number of units. In EPSEM sampling, the sample is an average unbiased estimate of the expected value. As far as the questionnaire is concerned, omnibus research has been carried out, which covered the employee's holiday habits and consumer priorities. The research covered the region of Zala County. In the correlation analysis, we are interested in the relationship between travel decision 
and age, and the significance of security. We performed correlation analysis to map the relationship between the variables.

The research seeks to find out what factors influence the consumer behavior in tourism in Zala County, how the residents see the security policy measures in their own and in the most visited areas, and how the authorities communicate with them. In addition, we investigated the main cultural and social features and the psychological needs of the subjects (e.g.: motivation, perception, attitudes) and their personal characteristics (e.g.: age) that may impact the destination selection process. What were the reactions of the authorities in tourism sector (Tourism Destination Management, Police, Department of Consular Affairs and Citizenship) to security issues in recent years in order to enhance the sense of security of tourists?

\section{RESULTS AND DISCUSSION}

The empirical results show that break times are decreasing due to the employers' influence or the employees' own expectations in Zala County. Non-stop working may cause not only fatigue and - in worse cases - burnout but, unfortunately, also long-standing illnesses. The biggest part of the Hungarian population would like to relax a lot quickly and feel the need to change; however, they cannot achieve it due to financial reasons or internal impulse. These factors influence the efficiency of the employee, which also has an impact on the success of the employer.

The results revealed that despite being overloaded, employees feel that it is natural to have more breaks because it increases performance; in addition, building common rooms help establish and maintain a good relationship between colleagues. There are, of course, peak hours (mostly in production, commerce, and hospitality) when there is less time to have a break, but they try to compensate the employees.

The quantitative results of the empirical research include the motivating factors that determine the employees' decisions. On a Likert scale (where 1 was the least typical and 5 was the most typical choice), we asked the respondents to mark the aspects they considered important (Tab. 1).

There is a strong emphasis on the appropriate price/value ratio (4-27.1\%; 5-62.4\%), but there is a significant sense of security $(4-25 \%, 5-59.1 \%)$, which results in looking for destinations where holiday makers do not feel threatened (Péter et al., 2018). 
Table 1 Main factors determining the travel decision (distribution)

\begin{tabular}{|l|c|c|c|c|c|}
\hline & $\mathbf{1}$ & $\mathbf{2}$ & $\mathbf{3}$ & $\mathbf{4}$ & $\mathbf{5}$ \\
\hline Dining options & $4.1 \%$ & $5.1 \%$ & $22.2 \%$ & $31.0 \%$ & $37.6 \%$ \\
\hline Number of services & $5.6 \%$ & $9.3 \%$ & $32.0 \%$ & $35.1 \%$ & $18.0 \%$ \\
\hline Price / value ratio & $0.6 \%$ & $1.0 \%$ & $8.8 \%$ & $27.1 \%$ & $62.4 \%$ \\
\hline Quality & $0.6 \%$ & $1.2 \%$ & $6.6 \%$ & $42.0 \%$ & $49.6 \%$ \\
\hline Sports facilities & $12.1 \%$ & $18.9 \%$ & $31.2 \%$ & $24.7 \%$ & $13.1 \%$ \\
\hline Wellness facilities & $11.6 \%$ & $12.7 \%$ & $23.2 \%$ & $28.0 \%$ & $24.5 \%$ \\
\hline Safety & $4.5 \%$ & $9.1 \%$ & $2.3 \%$ & $25.0 \%$ & $59.1 \%$ \\
\hline
\end{tabular}

Source of data: created by the authors, 201

In the hierarchy of needs, the physiological needs are immediately followed by the desire for security. Organized mass tourism fans who enjoy the so-called "all inclusive" travel packages and have little contact with the locals because it is the most enjoyable and secure way for them to rest, now have several similarities with the adventure travellers who need minimal security and comfort, travel independently, organize their trip individually, and gladly socialize with the local people.

Altogether $39.2 \%$ of the workers surveyed in Zala county spent their holiday abroad, while $60.8 \%$ chose a domestic destination. $47.8 \%$ choose a summer holiday, however, the results show that the duration shrank from the former 7-10 days to 5 days. The popularity of long weekends has not changed and is similar to the national average, with an average three-day stay. More than $90 \%$ of the consumers across the country use the Internet to access travel information, and almost every tour operator and travel agent has their own website. However, most service providers are not acquainted with the travellers seeking online information or receiving their services. This also means that they do not have sufficient data on the efficiency of their online sales activities or about their online target groups, either. To prevent this, tourism service providers should be advised to measure their website traffic and develop a website statistics software that allows them to make surveys easily. Data may include the location of visitors (e.g.: search engines, destination site) or how many people used basic (accommodation, programs) or additional tourist services (insurance) in certain period(s) (month, year) (Gyulavári \& Hubert, 2014). In addition, website statistics can help tour operators find the most visited menu points and place the most frequently "clicked" item in the most conspicuous area of their site. Most consumers feel the need to read other people's opinion in forums before travelling, but only a few travel agencies operate a forum on their website; the rest of them are not interested in creating such an online service, which consumers are missing. (Péter et al., 2018). According to the latest GFK data, based on a national representative survey on the holiday plans in 2017 involving 1,000 people, slightly more than half of the Hungarian 
population (54\%) plan to travel this summer, most of them (32\%) choose domestic locations, $10 \%$ travel abroad and $12 \%$ have both domestic and international destinations during the summer holiday. The most popular domestic destination remains Lake Balaton, while the Croatian, Greek and Italian beaches and Transylvania are the top foreign locations. Travel habits are clearly related to age, social and financial situation and place of residence. While 20to-29-year-olds typically travel abroad, the 40 to 49 year old population prefer to stay within the borders.

Half of the employees interviewed said that the common goals motivate them to accomplish a task, but they do not feel that they are asked for their opinions often enough when making decisions. $9 \%$ totally agreed that the management gives meaningful response to their proposals. Personal experience with security issues has a deep impact on travellers, since a single smile can make them return to a given destination, however, one negative experience is enough to discourage them permanently in the future.

The events attracting a large number of tourists have great significance; if the venue has a pleasant tourism image, there will be higher interest in tourism packages, consequently the packages may be put on sale. If the site does not have strong attraction, the recurring event can raise the visitors' interest in the destination and finally, albeit slowly, it will develop.

Most respondents choose a tourist destination (55\%), but accommodation (23\%) and events/programs (12\%) are also of paramount importance when making a decision. Security and fun-packed environment are the top priorities to remember (Fig. 2).

Figure 2 Motivating factors when making a travel decision (\%)

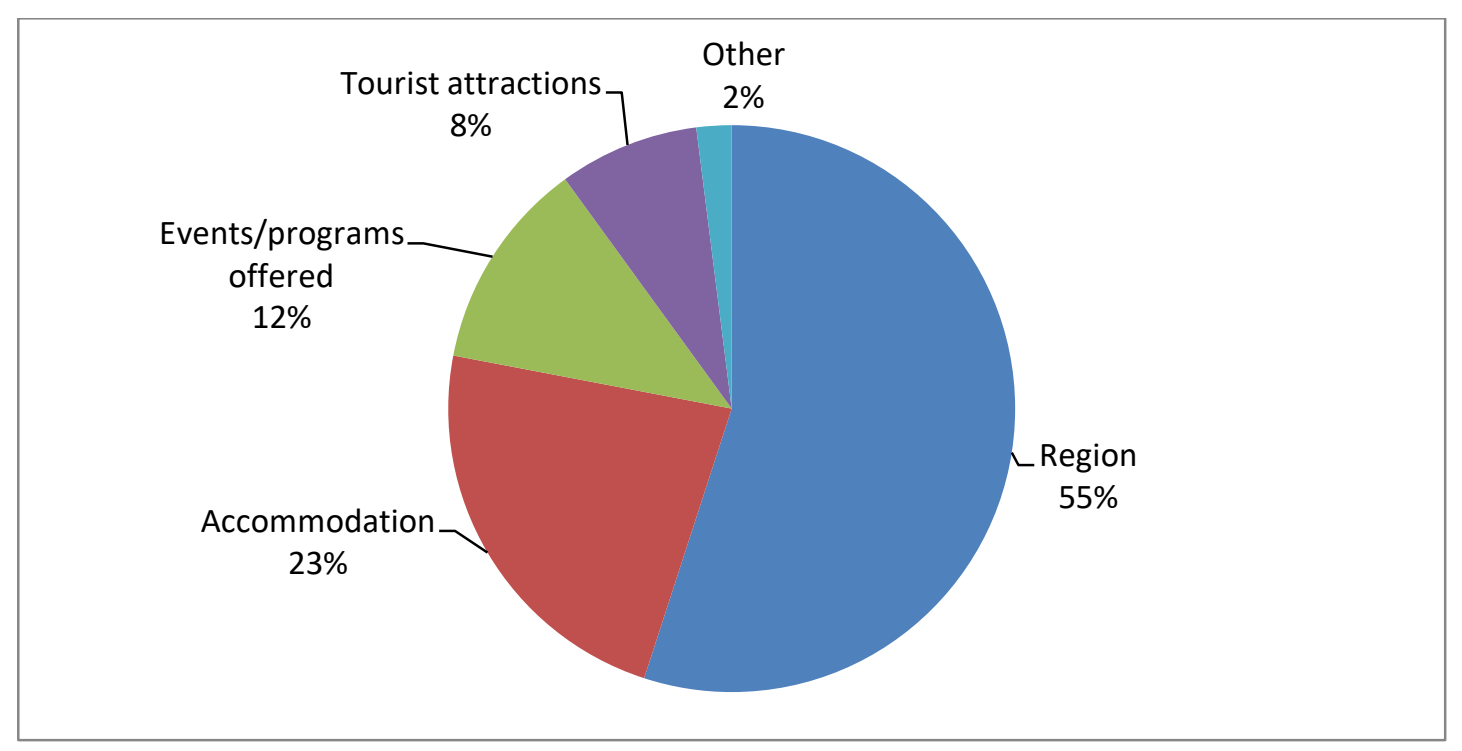

Source of data: created by the authors, 2017

Employees in Zala County still consider wellness eating and sleeping excessively. Since they "cannot waste their time," they want to discover new experiences (15\%) and look for adventure 
(6\%) that can make their holiday unforgettable; the respondents claim it can be carried out only in a calm and safe environment.

As Fig. 3 illustrates, the desire for rest and recreation is strong (33\%), however, in recent years discovering new experiences (15\%) and seeking adventures (6\%) have gained importance, which is typical of the respondents from generation $\mathrm{Y}$ and $\mathrm{Z}$. They are more determined to travel, even if they have less discretionary income, and feel that nothing bad can ever happen to them.

Figure 3 Distribution of objectives during the holiday (\%)

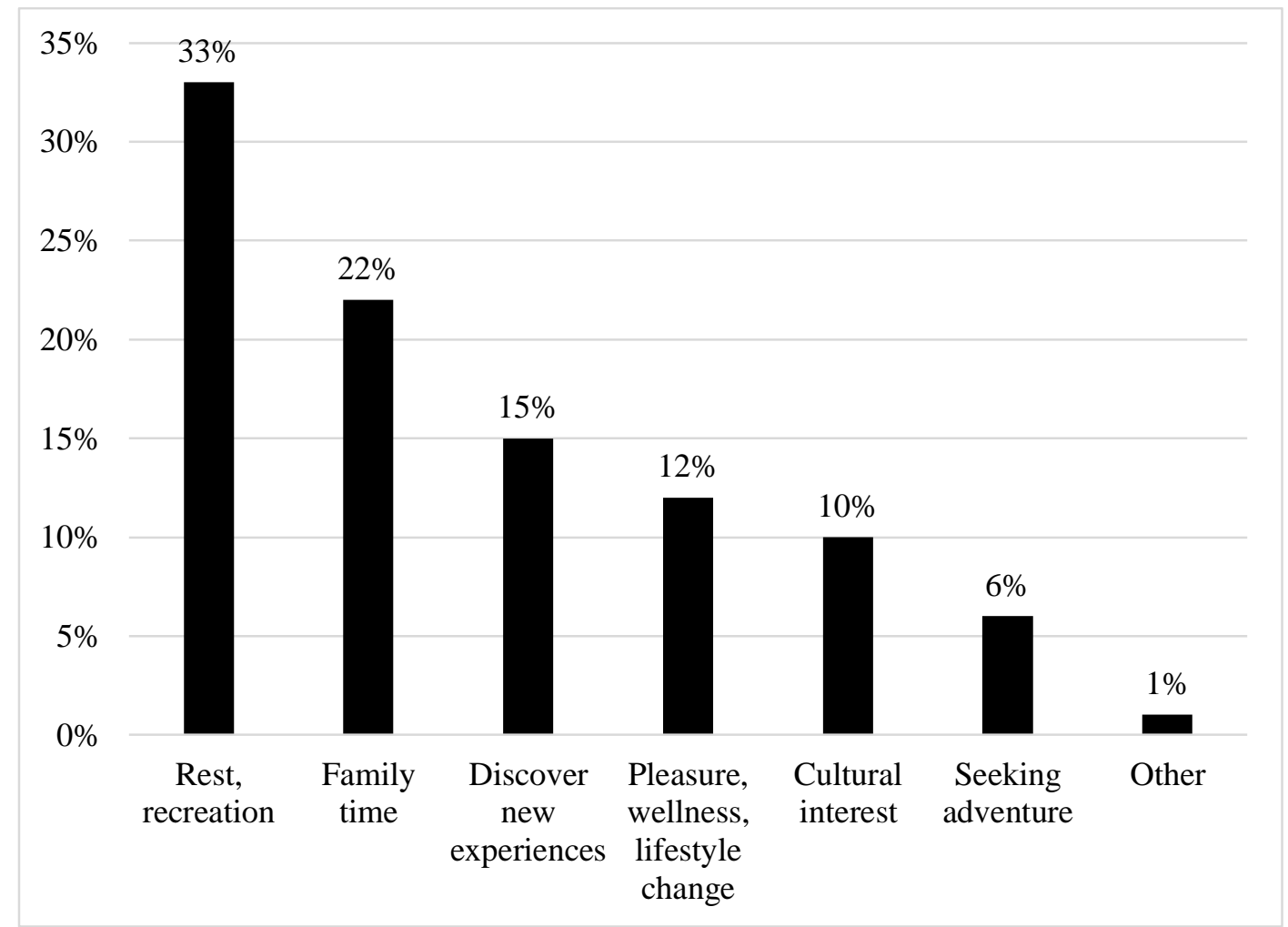

Source of data: created by the authors, 2017

When several places experience threats (domestic political affairs, terrorism, economic recession) all around the world, this could be a major setback to the further development of tourism. There may also take place a significant territorial reorganisation because the tourists will avoid the dangerous areas. In 2011, rebellions in North Africa and in the Middle East resulted in such shifts in geographical location. Similarly, environmental problems, pollution and disasters also influence the further development of the tourism industry and may discourage tourists from visiting certain locations or even larger regions. Hopefully, however, these political and environmental problems will not happen too often in too many places, and the new tourism trends discussed in this research will not be disrupted. 
The increasing terrorism threats and antipathy towards foreigners may influence the growth of tourism in some cultures, both quantitatively and qualitatively. Fig. 4 shows that more than half of the respondents $(55 \%)$ do not take the terrorist threats into account during their travel, but $22 \%$ decide on domestic holidays and do not travel abroad, because they consider Hungary safer.

Figure 4 The impact of terrorism on holiday habits (\%)

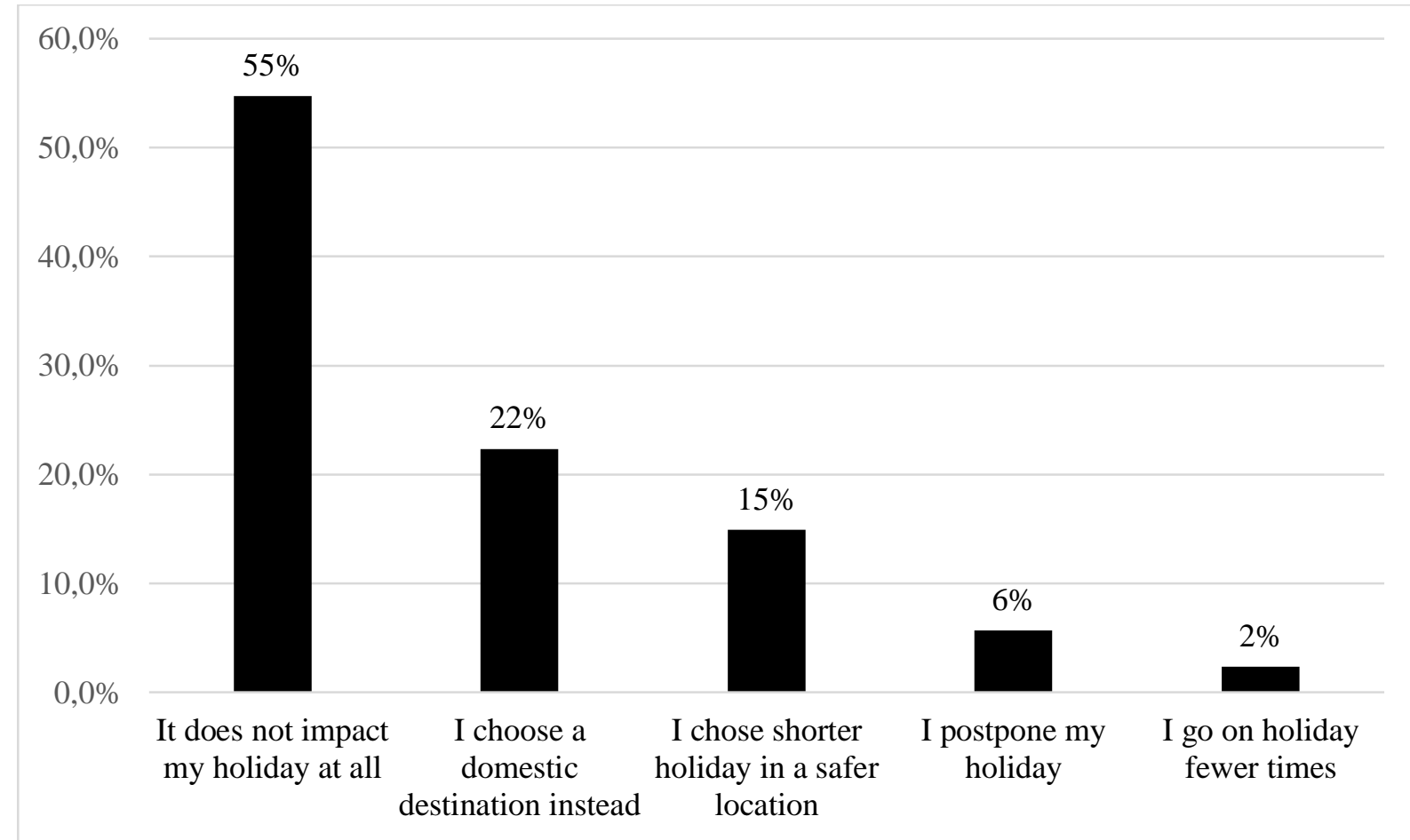

Source of data: created by the authors, 2017

Fortunately, Hungary is not a potential target of terrorist attacks. In 2017, the State initiated prior consultation regarding the security measures with the Constitution Protection Office and the Counter Terrorist Centre (professional bodies), and last but not least the local governments also got involved, says Kertész (2017). This solution allows the police to provide a secure escape route for the crowd. $75 \%$ of the respondents did not cancel any of their programs due to terror threats, but $25 \%$ rescheduled their trip and did not visit the planned events. The biggest proportion (11\%) stayed away from international sports matches.

The correlation analysis revealed strong relationship between travel decisions and age. It is interesting to point out that the Pearson correlation coefficient has negative value $(-0.718)$ at 0.0007 significance level. It shows a reverse relationship, i.e. the younger someone is, the more confidently they make decisions, and are not influenced by their financial background; when they are short of money they look for alternative options and use Internet forums to find cheap or free accommodation. When the body indicates the worker that it is time to rest, young people 
recognise the "danger" sooner; middle-aged and older respondents can only afford to relax "a lot, quickly", which presents new challenges not only to healthcare workers but also to tourism professionals.

\section{CONCLUSION}

Hungary is in a favourable position on the international list of safe destinations, ahead of several Western European states. This has a positive impact on foreign tourists and gives a competitive edge to domestic tourism, ensuring the livelihood of over four hundred thousand workers in a market that is also supported by state-sponsored developments.

The Hungarian Tourism Agency also works together with the Constitution Protection Office and the relevant government agencies and county governments. Tourism is a sector that is fundamentally determined by external circumstances, such as technological innovations, changes in travel habits, or precisely the current security situation.

The global terrorist threat is intensifying in many countries around the world. Risk management tasks and crisis management schemes are of greater importance than ever before. International cooperation among the national security organizations of each country is much appreciated, especially during major international events. Hungary is a safe country, which should be promoted and represented constantly. The activities of TDM organizations are becoming more valuable, as the professional organizations dealing with tourism have to play a pivotal role. Players in the management and tourism sector need to respond effectively to new challenges. In the context of conscious tourism planning, the management tasks of the host areas play a key role in the sustainable exploitation of the retention in the areas visited by tourists.

If tourists are open-minded, they can experience and see that the crimes are often committed in front of their eyes, or they may be offered various illegal "services". Therefore, it is important to inform and encourage all concerned parties to report suspicious cases to the police. In addition, it is also worth confronting the tourists, who may be potential criminals in many cases, with the consequences of crimes by means of campaigns (Ernszt, 2018).

Security plays a key role in travel decisions, which is supported by our empirical research and will be even more appreciated in the future. The proactive police work is crucial in tourism, because it helps the tourist to create a sense of security. In order to fulfil this task, it is necessary to work together with various tourism organizations and local governments, to achieve proper 
communication between the executive bodies and the society, the overall aim of which is to reduce the number of crimes, assist the victims of crime, and provide full counselling.

The aim is to emphasize security in all available media, and it is important to keep foreign partners and domestic customers up to date. The primary tools for the State to prevent panic are the appropriate diplomacy and consular service/delegation. The Hungarian Tourism Agency can also help develop a sense of security by creating a well-made image film, as well as appropriate destination management and event management (Péter, 2018).

The promise of peace and security is of the utmost importance for a tourist destination. Not only the lack of terrorist attacks, but also the lack of other crimes can be attractive. There are groups for whom tranquility is essential; especially for families with children and for the growing population of elderly people. Therefore, those destinations that can guarantee it also have to use it for marketing purposes. Approximately one third of the respondents participating in the research said that security issues would either make them choose a shorter vacation or domestic destinations. However, this does not necessarily means rescheduling, since the vast majority (86\%) does not cancel their programs.

In addition to personal security (hygiene, public security, tourist police) travellers put great emphasis on the security of property and on financial security. Preconceptions about the security of a destination strongly influence travel decisions. The role of social media in shaping preconceptions and spreading the reputation of experienced security has intensified.

The research has led to surprising results: while all the data at global, European and even national level clearly highlight the explosive development of the tourism industry, the research we carried out has come to the conclusion that even nowadays the economic crisis affects many people, as about one third of the respondents choose cheaper or shorter holidays. Thus, despite the ever increasing demand for high quality service, there is still a considerable segment of society that is forced to choose cheaper or shorter holidays. As a consequence, service providers need to satisfy the two requirements at the same time: travellers expect excellent service, safety and peace of mind at a reasonable price. At this point, the importance of hospitality cannot be emphasized enough. This may even slightly - but not completely - compensate for the fewer number of services or the lack of "luxury", or even more, it can make the holiday experience more beautiful and unforgettable.

Correlation studies proved that the younger generations make more confident decisions (and worry less about security) that may be independent of their financial situation. Both sexes considered the location of the holiday the main motivation. The participants of the survey return to areas that offered them positive experience, which can be utilised with emotional marketing 
propaganda. The activities of Tourism Destination Management organisations should be reconsidered; as professional organisations they should act as a driver in tourism and the management must respond effectively to new challenges even when dealing with suprastructures.

Crime prevention practices become remarkably important in tourism processes, because the century-old means of criminal law are ineffective to prevent the rapid criminal offences (Zsarnóczky, Molnár, \& Garamvölgyi, 2018).

As a consequence, any method, technique, and technology that restrict violent crimes are supported by both the society and the government. The international strategy for crime prevention also prefers social crime prevention; therefore, the state has an obligation to support local organizations actively involved in crime prevention. The aim of the European Union legislators is to establish a coordinated network of voluntary, self-motivated social groups operating efficiently. As for efficiency, local and subregional levels are of paramount importance. Individual strategies adjusted to each settlement can also be developed, whose design, adaptation, monitoring, feedback and decision-making are required by the whole process.

\section{Acknowledgement}

The research that founded the publication of Erzsébet Péter $\mathrm{PhD}$ was conducted within the framework of TÁMOP-4.2.4.A/2-11/1-2012-0001 'National Excellence Program'- Development and Operation of the Convergence Program of Inland student and Researcher Support. The project was supported by the European Union, co-financed by the European Social Fund.

\section{REFERENCES}

Alvarez, M. D. \& Campo, S. (2014). The influence of political conflicts on country image and intention to visit: A study of Israel's image. Tourism Management, 40, (2), 70-78.

Bacsi, Z. \& Kovács, E. (2016). Managing health tourism destinations: Theory and empirical research in Hungary, Saarbrücken: Scholar's Press, (ISBN:9783639863314), 122.

Bacsi, Z. (2018). Tourism competitiveness and security, III. International Scientific Conference on Tourism and Security, Zalakaros, 4 December 2018, ISBN 978-963-396-118-6

Barna, K., Nagy, M. Z., \& Molnár, T. (2006). Egyszerüen statisztika II. (Simply statistics II) Budapest, Perfekt Kiadó, ISBN:9633946689, 267.

Bayramov, E. \& Abdullayev, A. (2018). Effects of political conflict and terrorism on tourism: How crisis has challenged Turkey's tourism develoment In: Udvari, B., Voszka É. (eds) 2018: Challenges in National and International Economic Policies. University of Szeged, Doctoral School in Economics, Szeged, 160-175

BFTK (2019). BFTK-elemzés Budapest turisztikai piacáról (BFTK analysis of the tourist market in Budapest), Retrieved from: https://turizmus.com/szabalyozasorszagmarketing/bftk-elemzes-budapest-turisztikai-piacarol-1162263. 8 March 2019 
Bogáromi, E., \& Malota, E. (2017). Kulturális sokk és fogyasztói akkulturáció - kétirányú, interdiszciplináris megközelítésben (Cultural shock and consumer acculturation - a twoway, interdisciplinary approach), Vezetéstudomány, 48(4), 6-17.

Bowen, D., \& Clark, J. (2009). Contemporary tourist behaviour: Yourself and others and tourists. CABI. Cambridge, Cambridge University Press

Crotti, R., \& Misrahi, T. (eds, 2018). The travel \& tourism competitiveness report 2017, World Economic Forum, Geneva

Cotîrlea, D. A. (2015). Country image vs. country brand: differences and similarities, Ecoforum, 4(1), 165-171

Dann, G. M. S. (1977). Anomie, ego-enhancement and tourism. Annals of Tourism Research, 4(4), 184-194

Ernszt, I. (2018). Children from the unhappy side of tourism. Proceedings of the MakeLearn and TIIM International Conference. Naples, 16 - 18 May 2018, ISBN 978-961-6914-239

Ernszt, I., Péter, E., Keller, K., \& Tóth-Kaszás, N. (2018). Biztonsági kérdések a turizmusban - egy határ menti térség példáján keresztül (Security issues in tourism - through an example of a border region), Turizmus Bulletin, 18(2), 38-45

Europol (2017). European Union terrorism situation and trend report, European Union Agency for Law Enforcement Cooperation.

Fourie, J., Rosselló, J. \& Santana-Gallego, M. (2015). Religion, religious diversity and tourism. Kyklos, 68, 51-64

Gyulavári, T., \& Hubert, J. (2014). A hatásosság és hatékonyság fogalmainak értelmezése online vs. offline kampányok keretében (Interpreting concepts of effectiveness and efficiency in online vs. offline campaigns). In: Hetesi Erzsébet, Révész B (szerk.). "Marketing megújulás": Marketing Oktatók Klubja 20. Konferenciája ("Marketing Renewal": Marketing Teachers Club 20th Conference). Szeged: SZTE GTK, 302-310.

IPSOS (2017). Retrieved from: https://www.ipsos.com/sites/default/files/ct/news/documents/201805/Ipsos_Europ_Assi stance_Barometre_Edition2018-EN.pdf, 27 January 2019

Hall, M., Williams, A. \& Lew, A. (2004). Tourism: conceptualizations, institutions, and issues. In Hall, M., Williams, A.\& Lew, Alan (eds).: A companion to tourism. Oxford, Blackwell. 3-21.

Kantar, S. \& Svržnjak K. (2017). Development of sustainable rural tourism, Deturope - The Central European Journal of Regional Development and Tourism, 9, (1), 26-34.

Kertész, R. (2018). Önfeledt szórakozás biztosítása, egy kihívásokkal teli tömegrendezvényen, szerk.: Németh K.-Péter E. - Kiglics N.; II. Turizmus és Biztonság Nemzetközi Tudományos Konferencia, Zalakaros, 2017.12.01, (Providing pleasant entertainment at a challenging mass event, edited by Németh K.-Péter E. - Kiglics N.; II. International Conference on Tourism and Security, Zalakaros, 1 December 2017) ISBN 978-963-396102-5

Király, L., \& Vájó, N. (2015). Rendezvények biztonsági kérdései (Security issues for events), Hadmérnök, 10(1), 11-23.

Konzuli és Állampolgársági Főosztály (Department of Consular Affairs and Citizenship) (2019). France, Retrieved from: http://konzuliszolgalat.kormany.hu/europa-utazasitanacsok?franciaorszag, 6 March 2019

Kővári, I. \& Zimányi, Z. (2017). Safety and security in the age of global tourism (The changing role and conception of Safety and Security in Tourism) Applied Studies in Agribusiness and Commerce - Apstract Agroinform Publishing House, Budapest, 59-61.

KSH (Hungarian Central Statistical Office) (2018). A beutazó turizmus jellemzői és alakulása 2017-ben - A KSH keresletfelmérésének adatai alapján, Magyar Turisztikai Ügynökség 
(Characteristics and development of incoming tourism in 2017 - Based on the data of the HCSO's demand survey, Hungarian Tourism Agency), Retrieved from: https://mtu.gov.hu/documents/prod/Beutazo_kereslet_2017_2.pdf, 25 January 2019

Magyar Turisztikai Ügynökség (Hungarian Tourism Agency) (2017). A magyar lakosság belföldi és külföldi utazásai 2016-ban - A KSH keresletfelmérésének adatai alapján (Domestic and foreign trips of the Hungarian population in 2016 - Based on the data of the HCSO's demand survey), Budapest, 10 March 2017.

Maslow, A. (1954). Motivation and Personality. Harper, New York

Michalkó, G. (in press). A biztonság szerepe a turizmus rendszerében (The role of security in the tourism system), In: Michalkó, G., Németh, J., \& Ritecz, G. (ed.), Turizmusbiztonság (Tourism Security), Dialóg Kiadó, 8-12

Michalkó, G. (2012). Turizmológia - Elméleti alapok (Tourismology - Theoretical foundations) Budapest, Akadémiai Kiadó, 9.

Martin I. M. \& Eroglu, S. (1993). Measuring a multi-dimensional construct: country image, Journal of Business Research, 28 (3), 191-210

Oláh, T. (2010). Turizmus és közbiztonság kapcsolata Salgótarján példáján (The relationship between tourism and public safety through the example of Salgótarján), Gyöngyös, p. 61. IN: Bujdosó Z.- Györki M.: A biztonság szerepe a turizmusfejlesztésben (The role of security in tourism development), Acta Carolus Robertus, 1(2), 45-56

Péter, E., Németh, K. \& Lelkóné Tollár, I. (2018). Turizmusbiztonság, mint újonnan felmerülő fogyasztói igény (Tourism security as a newly emerging consumer demand), Turizmus Bulletin (Tourism Bulletin), 18(2), 30-37

Péter E., \& Németh, K. (in press). Turisztikai célterületek kockázatmenedzsmentje, a fogadóterületek menedzselési feladatai (Risk management of tourist destinations, management tasks of host areas) In: Michalkó Gábor - Németh József - Ritecz György (ed.), Turizmusbiztonság (Tourism Security), Dialóg Kiadó,109-110

Pizam, A. \& Mansfeld, Y. (eds.) (1996). Tourism, crime and international security issues. New York, John Wiley and Sons

Pusztai, B. (2013). A turista jóllét forrása - Találkozás az autentikus látnivalóval vagy igazi önmagunkkal, szerk: Michalkó G., \& Rátz T.: Jó(l)lét és turizmus: utazók, termékek és desztinációk a boldogság és a boldogulás kontextusában, (The source of the tourist wellbeing - Meeting the authentic attraction or with our true self, edited by G. Michalkó - T. Rátz: Well-being and tourism: travelers, products and destinations in the context of happiness and prosperity,) Székesfehérvár-Budapest, Kodolányi János Főiskola MTA CSFK Földrajztudományi Intézet Magyar Földrajzi Társaság, ISBN: 978-615-5075-15-5 ISSN: 1786-2310, 13-21.

Ranga, M. \& Pradhan, P. (2014). Terrorism terrorizes tourism: Indian Tourism effacing myths? International Journal of Safety and Security in Tourism. 1(5), 26-39

Ritchie, B. W. (2004). Chaos, crises and disasters: A strategic approach to crisis management in the tourism industry, Tourism Management, 25(6), 669-683

Rittichainuwat, B. N. \& Chakraborty, G. (2009). Perceived travel risks regarding terrorism and disease: The case of Thailand. Tourism Management, 30(3), 410-418

Saha, S., \& Yap G. (2013). The moderation effects of political instability and terrorism on tourism development: A cross-country panel analysis, Retrieved from: https://doi.org/10.1177/0047287513496472, 16 March 2019

Simay, A. \& Gáti, M. (2017). A fogyasztói jelenlét és a nyilvánosság iránti attitüdök vizsgálata a mobil és közösségi médiában (Examining consumer presence and public attitudes in mobile and social media), Vezetéstudomány, 48(1), 61-69

Sönmez, S. F. (1998). Tourism, terrorism, and political instability. Annals of Tourism, Research, 25(2), 416-456 
Thapa, B. (2004). Tourism in Nepal, Journal of Travel \& Tourism Marketing, 15(2-3), 117138

Tolman, E. C. (1959). Principles of purposive behavior. In: Koch, S. (ed). Psychology: A Study of a Science, New York, McGraw-Hill, 92-157

Turizmus Online (Tourism Online) (2016). Turizmus terrorizmus idején (Tourism at the time of terrorism), Retrieved from: http://turizmusonline.hu/kulfold/cikk/turizmus_terrorizmus_idejen, 19 February 2018

Turizmus Online (Tourism Online) (2017). A magyarok fele tervez nyaralást idén (Half of the Hungarians are planning a holiday this year), Retrieved from: http://turizmusonline.hu/belfold/cikk/a_magyarok_fele_tervez_nyaralast_iden, 27 January 2019

Zsarnóczky, M., Molnár, L. \& Garamvölgyi, L. (2018). Bünmegelőzés a turizmus által érintett közösségekben (Crime prevention in communities affected by tourism), III. International Scientific Conference on Tourism and Security, Zalakaros, 4 December 2018. 